\title{
The Use of Metacognitive Strategies in Reading and their Influence on Reading Comprehension of Junior High School Students in the Upland Region of Java
}

\author{
Melly Latifah, ${ }^{a}$ Sri Hartati R. Suradijono, ${ }^{b *}$ and Lucia Retno Mursitolaksmic \\ ${ }^{a}$ Faculty of Psychology, Universitas Indonesia, Depok, Indonesia; ${ }^{b}$ Department of \\ Developmental Psychology, Faculty of Psychology, Universitas Indonesia, Depok; ${ }^{c}$ Department \\ of Educational Psychology, Faculty of Psychology, Universitas Indonesia, Depok \\ *Corresponding Author: \\ Sri Hartati R. Suradijono \\ Developmental Psychology Department \\ Faculty of Psychology, Universitas Indonesia \\ Jl. Lkr. Kampus Raya, Depok, Jawa Barat \\ Indonesia, 16424 \\ Tel.: +62 217270004 \\ E-mail: shsrdjn.192us@gmail.com
}




\title{
The Use of Metacognitive Strategies in Reading and their Influence on Reading Comprehension of Junior High School Students in the Upland Region of Java
}

\begin{abstract}
Reading comprehension plays an important role in students' academic achievement. One's level of reading comprehension is shown to be related to the use of metacognitive strategies in the reading process. This study will identify the types of metacognitive strategies used in the reading process by 55 junior high school students in the upland region of Java, and it will analyze the influence of these strategies on students' reading comprehension. In this study, a think-aloud procedure was applied to identify the types of metacognitive strategies students used during the reading process. This study found 15 types of metacognitive strategies and divided them into two groups based on Perffeti's dichotomy (1989): (1) strategies for achieving the meaning of the text (7 types); and (2) strategies for achieving the interpretation of the text ( 2 types). The rest of six types are considered "transitional strategies" (Suradijono, 2003). The second group represents a higher level of metacognitive strategies because they involve complex information processing. This study indicated that students more commonly use the first set of strategy types. The results also showed that the three metacognitive strategies of Repetition, Knowledge Evaluation, and New Knowledge had a significant effect on reading comprehension. This research recommends metacognitive scaffolding training to enhance student skills in using metacognitive strategies to improve reading comprehension.
\end{abstract}

Keywords: metacognitive strategies, reading comprehension, think-aloud, upland.

\section{Introduction}

Reading comprehension is a very important skill in learning (Klingner, Vaughn, \& Boardman, 2007; Williams \& Atkins, 2009), and it is a critical aspect of student success in school, as well as in later life (Dorn \& Soffos, 2005). At the latest, students' reading ability must increase from learning-to-read to reading-to-learn by the $8^{\text {th }}$ grade. Otherwise, students will have trouble in various subjects at the next school level (Chall, 1979). Reading comprehension describes the process of building knowledge that involves processing information at a higher level than simply recording it (Brown \& Palincsar, 1989). To understand reading, strategies are needed that connect new information with existing knowledge (Jonassen, 1987). Those strategies are metacognitive aspects that researchers consider very important in the process of achieving successful reading comprehension (McKeown \& Beck, 2009).

Metacognitive strategies are rooted in metacognition theory. First coined by Flavel, the term metacognition is defined as thinking about one's own cognitive processes (Flavel, 1979). Metacognitive strategies are defined as ways of controlling and organizing the mind (Schunk, Pintrich, \& Meece, 2008). Good thinkers routinely use their metacognitive strategies to solve problems or tasks. They recognize when and where to use them because good thinkers always monitor their learning situations (Santrock, 2011). In the reading comprehension process, this metacognitive strategy is very important (Snow, 2002; Block, 2004).

To complete a reading comprehension task successfully, a student must proactively process text by activating prior knowledge and applying various metacognitive strategies (Dorn \& Soffos, 
2005; McNamara, 2007) and use metacognitive knowledge and its strategies consciously and earnestly (Karbalaei, 2011). Considering the definition of Flavel's metacognition (1979), the reading activity essentially involves two elements of metacognition: metacognitive awareness; i.e., what the reader knows; and metacognitive regulation; the reader knows when, where, and how to use strategy while reading. This self-regulatory behavior determines learning outcomes (Winne \& Nesbit, 2009) and academic achievement (Zimmerman, 1990). The expert reader is coordinating the metacognitive strategies they have when comprehending the reading material (Klingner, et.al, 2007). Some research indicates that good readers use more strategies in reading than poor readers do (Lenski \& Nierstheimer, 2002).

Research of metacognitive strategies in reading comprehension began to be in demand in the 1990s. Among its pioneers are Bereiter and Scardamalia (1985). Their results found three levels of metacognitive strategies used by study participants when understanding the text. Level 1 expresses interest in information from the text it formulates in the form of questions; Level 2 identifies common little-known schemes; and Level 3 identifies parts of the text that are not understood (Suradijono, 1989). Using Bereiter and Scardamalia's scale, Suradijono (1989) conducted research on primary school students in Canada and discovered three new scales.

In Indonesia, the study was continued by Suradijono (1999) with high school students in Depok and Jakarta; new metacognitive strategies resulting in 16 metacognitive strategy types were successfully identified. This research was continued by Latifah (2002) with junior high school students in Bogor, and the same type of metacognitive strategy was found as Suradijono's, with only a difference found between the use by expert and novice students. Expert students' use of metacognitive strategies was better in quality and quantity than that of novice students. Taking into consideration that the use of individual metacognitive strategies is inseparable from mental development, and higher order thinking varies with culture and history (Van der Veer, 2007), it is interesting to continue this research based on cultural context.

One example of metacognitive research related to culture is research done by Turingan and Yong-Chil (2009). However, this study is not specific about metacognitive strategies in reading comprehension. The results show that the self-regulated learning ability of Filipino students is higher than that of Korean students, and presumably, the cultural and educational context of each country is a contributing factor. This aligns with the Vygotskian theory that states that the development of higher mental processes depends on the existence of a mediating agent in children's interactions with the sociocultural environment (Kozulin 2003). In those interactions, the thinking process became a higher level process. Based on the theories and empirical facts, it is very interesting to examine the use of metacognitive strategies in reading comprehension from an Indonesian cultural context.

The Javanese are the largest tribe in Indonesia, and some live in the upland region of Java. The upland Javanese culture is heavily influenced by Hindu culture (Irianto \& Thohir, 2000) and has characteristics that fit with the cultural characteristics of the Javanese palace (Jatman, 1993). The character of the Javanese in the upland region is described as gentle and concerned about feelings (Jatman, 1993). Considering the importance of metacognitive strategies for reading comprehension, as described earlier, research on the use of metacognitive strategies in reading comprehension on the upland Javanese becomes very important. There are two research 
problems to be answered in this research: (1) Which metacognitive strategies do junior high school students in the upland regions of Java use? (2) Do the metacognitive strategies the students use influence their reading comprehension?

\section{Methods}

\section{Participants}

This study was conducted within upland Javanese culture. The participants in this study were 55 8th grade students in junior high school, consisting of 32 female and 23 male, aged between 13.5 and 15.9 years $($ mean $=14.3$ years).

\section{Research Design}

This research used a non-experimental research design. This study controls for the participant's cultural context. The Gemarang District, Madiun Regency, East Java Province was chosen to represent the upland area.

\section{Measures}

- Reading Comprehension Test. A reading comprehension test was given to students before and after conducting the think-aloud procedure. This test was used to measure students' prior knowledge and reading comprehension.

- Think-aloud technique. The think-aloud technique was used to identify which metacognitive strategies were used by students while reading.

- Standard Progressive Matrices (SPM). This study controlled for a cognitive ability variable through measurement of basic intelligence level using the Standard Progressive Matrices (SPM) measuring instrument as conducted by a Psychologist. Measurement of the level of basic intelligence was intended as the control variable. This is because cognitive ability influences reading comprehension (Kintsch, 1998; Tierney \& Pearson, 1994; Nation, et.al, 2002). Therefore, in this study, students with a low cognitive ability (categories IV and V) were excluded.

\section{Procedure}

This research includes three stages of research: (1) preliminary research; (2) research implementation; and (3) data processing and analysis.

Preliminary Research. Preliminary research was conducted in the form of a survey to find out the most interesting reading topic. This study involved 318 th grade students in one junior high school location. This study found that the most requested topic was The Universe. This topic was then used to stimulate the process of collecting verbal protocol data (think-aloud) to find metacognitive strategies used by students.

Implementation of Research. In this study, metacognitive strategy data was collected using think-aloud techniques. These techniques have been used by many researchers, including Bereiter and Scardamalia (1985), Suradijono (1989, 1999), and Latifah (2002), among others.

The main data collection procedure began with the researcher's explanation of the verbal protocol using the think-aloud technique. After that, the researcher read the text and demonstrated the think-aloud procedure while reading the text. Then, the students were each 
asked to do a think-aloud procedure exercise until they really understood how it worked so that it could be done during verbal protocol data collection.

Before collecting verbal protocol data, students were given ten reading comprehension questions to measure their prior knowledge. Then, data collection of think-aloud verbal protocols was conducted in order to learn which metacognitive strategies were used. This procedure was not time constrained. After that, students were asked to answer ten reading comprehension questions. All of these procedures were recorded. On different occasions, the cognitive ability data was collected through the SPM test.

\section{Data Analysis}

The data collected from 55 students about the think-aloud verbal protocols were stored in the form of sound recordings with durations ranging from 40 to 90 minutes per student. The transcription process for each student's verbal protocol data into written form took approximately 2-4 hours per student. From the transcription results, there were 55 think-aloud protocols in the form of writing on sheets of paper. The sheets of paper for each protocol varied from 6 to 12 single-spaced pages of A4-sizes paper. On average, each student had 7 written sheets of think-aloud protocol. From 55 students, we collected 412 pieces of think-aloud protocols to be analyzed for type and number of metacognitive strategies used.

The data for metacognitive strategy use was derived from the result of the data analysis of verbal protocol using a guideline for classifying metacognitive strategies. The guideline was developed in this study and has a fairly good reliability $(\mathrm{r}=0.78)$. This guideline is based on the guidelines developed by Suradijono (1999) and Latifah (2002). By using this guideline, each student's verbal protocol was analyzed qualitatively to identify metacognitive strategies that arose during the process of reading material comprehension. In this analysis, the researcher carefully read the protocols from each student and identified any strategies that arose from the sentences or phrases spoken by the student, including the accompanying gestures. From the analysis results, we learned what types of metacognitive strategies were used and how many uses each student had; that is, each student's metacognitive strategy score was analyzed statistically.

After going through the processing stage, all data were analyzed descriptively and inferentially. A multiple regression test was conducted to determine the effect of metacognitive strategy on reading comprehension. Statistical analysis was performed with the SPSS Version 11.0 statistic software package.

\section{Results}

The basic intelligence scores ranged from 32 to 55 (with mean= 40.49, and $S D=5.01$ ). Eighty percent of students tested at a basic intelligence at an average level (category III). Prior knowledge plays an important role in reading comprehension (Dorn \& Soffos, 2005; Koda, 2007; Snow, 2002). In this research, the prior knowledge was measured before the think-aloud procedure was conducted. The result showed that the prior-knowledge scores ranged from 0 to 7 (with mean $=2.76$, and $S D=1.89$ ). Student reading comprehension is a score that was obtained from the prior knowledge scores; that is, the reading comprehension score was obtained before the think-aloud procedure and another reading comprehension score was obtained after the think- 
aloud procedure was conducted. The achievement score describes how much comprehension students had after being given information in the form of stimulant reading material on the topic The Universe. The results showed that the achievement scores ranged from 0 to 18 (with mean=6.51, and $S D=3.95$ ). An achievement score of zero indicated that the prior-knowledge score and achievement scores were the same. In other words, after reading the material, the students' knowledge was not increased; it was the same as it had been before reading the material.

\section{Types of Metacognitive Strategies Successfully Identified in Students}

From the results of verbatim data analysis, 15 types of metacognitive strategies were identified. These were Problem-Awareness, Text Evaluation, Meaning, Reread, Repetition, Problem-What, Ask-for-Information, Knowledge Evaluation, Problem-Gap, Problem-Hypothesis, Paraphrase, New Knowledge, Verification, Inference, and Elaboration. Descriptions of these 15 types of metacognitive strategies follow:

- Problem-Awareness. The student shows his lack of comprehension of the text he is reading, but has no interest in finding out more information from the text. Example:

Text: Kelompok bintang yang benar-benar dapat dilihat ialah gugus bintang yang disebut Plei.... Pleiades, atau Bintang Tujuh.

Student: "Gak pernah denger..."

- Text Evaluation. The student tries to give an assessment or opinion or express an impression about the text. Example:

Text: Herschel semakin meyakini bahwa Andromeda terdiri atas kumpulan bintang-bintang. Teori ini dibuktikan kebenarannya pada tahun 1923 oleh ilmuwan Amerika, Edwin Hubble...

Student: "Kok bahasanya aneh ya? [mengernyitkan dahi]"

- Meaning. The student tries to explain a word or phrase or a term contained in the text. Example:

Text: ....tetapi ada juga diantaranya yang tidak mempunyai bentuk tertentu.

Student: "Berarti gak beraturan sama gak bulat aja ya."

- Reread. The student indicates an interest in being able to understand the text by rereading the text. Example:

Text: Ruang angkasa mengandung butir-butir zat serta bermacam-macam gas dan radiasi. Alam semesta luasnya tidak terkirakan. Di alam semesta terdapat milyaran tata bintang yang disebut galaksi. Galaksi adalah kumpulan jutaan atau milyaran bintang. Student: "Galaksi adalah kumpulan jutaan atau milyaran bintang."

- Repetition. The student indicates an interest in being able to understand the text by repeating a word or phrase that he has read more than once for the purpose of remembering or memorizing. Example:

Text: Selain planet dan bintang, ada benda angkasa yang disebut satelit, yaitu benda yang beredar mengelilingi benda lain. Planet dapat dikatakan satelit matahari, sementara itu bulan merupakan satelit bumi.

Student: "Bulan merupakan satelit bumi... bulan merupakan satelit bumi."

- Problem-What. The student indicates an interest in being able to understand the text by asking questions about things in the text that he still does not fully understand. Example:

Text: Tampaknya seperti tambalan yang kabur...

Student: "Tambalan yang kabur ini maksudnya apa?" 
- Ask-for-Information. The student needs more relevant information with the text to further enrich his comprehension. Therefore, the student asks questions to obtain additional information. Example:

Text: Galaksi kita disebut Bimasakti, Student: "Kok bisa ya disebut bimasakti?"

- Knowledge Evaluation. The student is interested in reassessing whether or not their knowledge is true or false. In other words, the student tries to assess their prior knowledge by using the knowledge he has gained from the text. Example:

Text: Beberapa buah bintang ukurannya lebih kecil daripada bumi, yang lainnya beribu kali lebih besar dari bumi. Walaupun kebanyakan bintang menyinarkan cahayanya secara mantap, tapi ada juga yang hanya terlihat berkelap-kelip saja. Matahari merupakan salah satu jenis bintang.

Student: "Matahari salah satu jenis bintang. Saya kira planet [tersenyum sambil menggoyangkan kaki]"

- Problem-Gap. The student realizes that there is a gap between the knowledge he had and the information he has just learned from the text. Example:

Text: Yang dimaksud benda-benda langit yaitu bintang-bintang dan planet-planet. Bintangbintang berbeda ukuran dan sifatnya. Beberapa buah bintang ukurannya lebih kecil daripada bumi, yang lainnya beribu kali lebih besar dari bumi.

Student: "Bukannya bintang itu kecil?"

- Problem-Hypothesis. The student indicates a problem in comprehending the text. To solve the problem, the student tries to find answers by asking questions as well as by trying to form alternative answers or guesses or hypotheses based on his prior knowledge. Example:

Text: ...dan banyak peralatan lain untuk membantu mereka menemukan lebih banyak lagi tentang alam semesta. Mereka bekerja dalam suatu bangunan yang disebut observatorium,

Student: "O, mungkin seperti rumah."

- Paraphrase. The student tries to repeat the text in his own words. In this case, the student does not add any new information to his sentence. Example:

Text: Untuk mengamati ruang angkasa, para ilmuwan menggunakan satelit buatan.

Student: "Untuk melihat ruang angkasa, menggunakan satelit buatan."

- New Knowledge. The student shows or states that the information from the text he read is something new. Example:

Text: Sedangkan orang-orang yang menjelajahi ruang angkasa disebut astronot atau kosmonot.

Student: "Baru dengar nama kosmonot."

- Verification. The student has an attitude when he discovers a gap between the information from the text and his prior knowledge. Example:

Text: Sekarang para ilmuwan sedang mencari planet yang kesepuluh. Astronom purba menganggap semua planet tampak sebagai bintang.

Student: "Tapi menurutku itu tidak benar."

- Inference. The student forms a conclusion or essence or summary of the text he is reading. Example:

Text: Selain bintang, benda ruang angkasa lainnya adalah planet. Kata planet berasal dari bahasa Yunani yang berarti pengembara. [jari kiri ditemperlkan di bibir]

Student: "Berarti planet adalah benda yang pengembara." 
- Elaboration. The student attempts to add relevant information to enrich the information from the text, but not for the purpose of inference. Example:

Text: Karena itulah pusat bola menjadi panas.

Student: "Di dalamnya mengandung energi."

\section{Use of Metacognitive Strategies by Students}

To answer the first research question "Which metacognitive strategies do junior high school students in the upland regions of Java use," we conducted an analysis of the identified metacognitive strategy data from this study. In this case, the use of metacognitive strategies is viewed from two perspectives: the number of student users of each type of metacognitive strategy, and the frequency of use of each type of metacognitive strategy. The data show that the number of student users of each strategy type varies greatly; the range is between 7 and -48 students. The metacognitive strategies used by the lowest number of students are Knowledge Evaluation, Problem-Hypothesis, and Elaboration (each used by $12.73 \%$ of students). Meanwhile, the metacognitive strategy with the largest number of users is the Reread-Strategy (87.2\% of students).

As seen in Figure 1, the Reread, Problem-What, Ask-for-Information, Paraphrase, New Knowledge, and Inference strategies were used by more than half of students. On the contrary, Knowledge Evaluation, Problem-Hypothesis, Elaboration, Text Evaluation, and Verification were used by fewer than $20 \%$ of the students. The frequency of each metacognitive strategy use was measured by the frequency of student responses appearing in the form of the strategy used when reading the stimulant material provided by the researcher. The research results show that the average frequency of student use for all metacognitive strategies in total while reading the material was as high as 51.58 responses per student $(S D=34.04)$. When viewed from the perspective of each type of metacognitive strategy, the data shows that the Reread strategy had the highest frequency of use with 807 responses, which averages 14.67 responses per student. The second largest frequency of use was the New Knowledge strategy with a total frequency of 715 responses (mean=13 responses per student). Two other strategies that were found to have considerable use were the Problem-What with a total frequency of 312 responses (mean = $5.67 /$ student), and the Ask-for-Information with a total frequency of 258 responses (mean = 4.69/student). In contrast, the Elaboration strategy had the least frequency of use, with a total frequency of only 9 responses (mean $=0.16$ response/student). The Knowledge Evaluation had the second smallest frequency with a total of 11 responses (mean $=0.20 /$ student), followed by the Verification strategy with 19 respondents (mean $=0.35 /$ student). The Problem-Hypothesis strategy had 23 responses (mean=0.42 response/student), while Text Evaluation counted 25 responses (mean $=0.45$ response/student). 


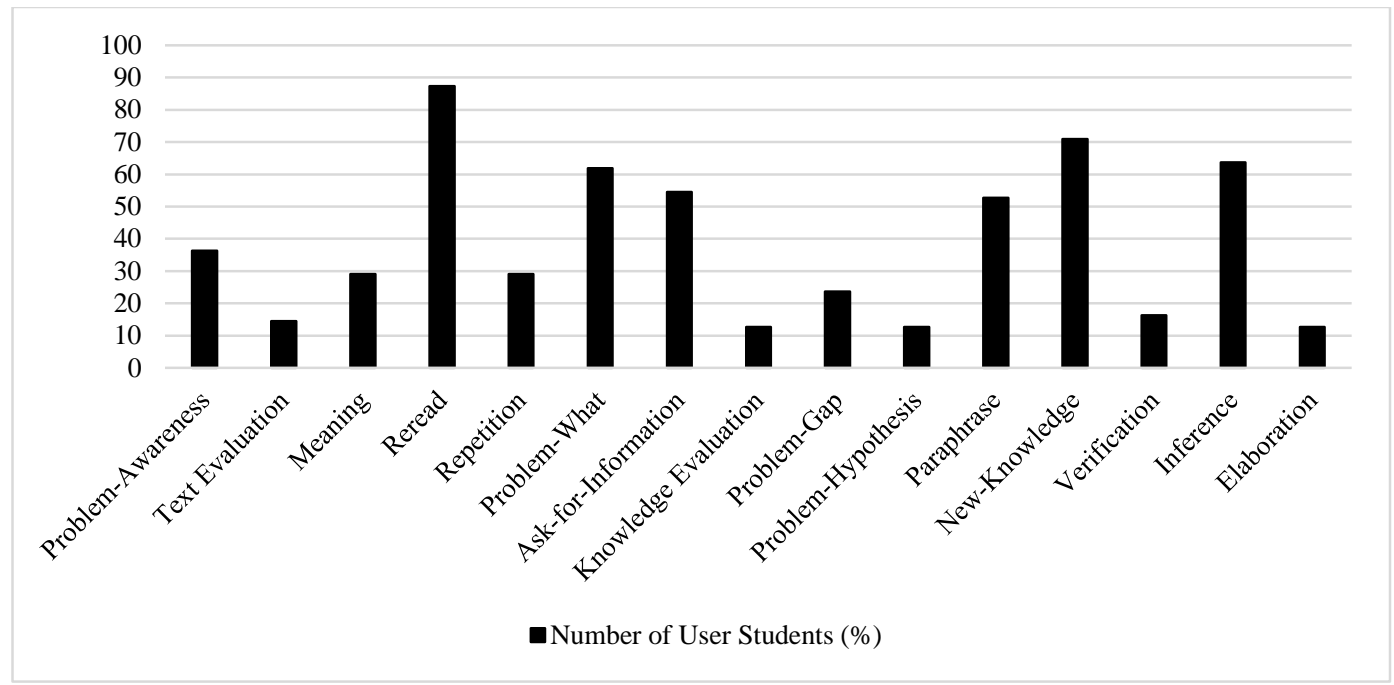

Figure 1. The Number of Student Users of Any Type of Metacognitive Strategy

\section{Influence of Using Metacognitive Strategies to Increase Reading Comprehension}

To answer the second research question "Do the metacognitive strategies the students use influence their reading comprehension," we analyzed the effect of metacognitive strategies on reading comprehension. The results of regression testing showed that metacognitive strategies do affect reading comprehension. This test was significant, $F(15,39)=2.149, p \leq 0.028$, Adjusted $\mathrm{R}^{2}=0.242$. Metacognitive strategies that significantly influenced reading comprehension were Repetition, Knowledge Evaluation, and New Knowledge (see Table 1).

Table 1

Regression Analysis Summary for Metacognitive Strategies Predicting Reading Comprehension

\begin{tabular}{|c|c|c|c|c|c|}
\hline Variable & B & SE B & $\beta$ & $t$ & $p$ \\
\hline Problem-Awareness & -.555 & .373 & -.496 & -1.488 & .145 \\
\hline Text Evaluation & .019 & .643 & .010 & .030 & .977 \\
\hline Meaning & .135 & .503 & .051 & .268 & .790 \\
\hline Reread & .067 & .038 & .282 & 1.794 & .081 \\
\hline Repetition & -.638 & .295 & -.274 & -2.164 & $.037^{*}$ \\
\hline Problem-What & .051 & .089 & .098 & .573 & .570 \\
\hline Ask-for-Information & -.137 & .088 & -.247 & -1.551 & .129 \\
\hline Knowledge Evaluation & 2.018 & .817 & .390 & 2.470 & $.018^{*}$ \\
\hline Problem-Gap & .311 & .553 & .182 & .563 & .576 \\
\hline Problem-Hypothesis & .159 & .507 & .084 & .314 & .755 \\
\hline Paraphrase & -.130 & .093 & -.194 & -1.402 & .169 \\
\hline New Knowledge & .135 & .041 & .579 & 3.326 & $.002 * *$ \\
\hline Verification & -1.271 & 1.049 & -.317 & -1.211 & .233 \\
\hline Inference & .231 & .127 & .406 & 1.820 & .076 \\
\hline Elaboration & 1.995 & 1.651 & .253 & 1.209 & .234 \\
\hline
\end{tabular}

Note. $R^{2}=0.242(N=55, p<0.05)$ 


\section{Discussion}

We successfully identified 15 types of metacognitive strategies: Problem-Awareness, Text Evaluation, Meaning, Reread, Repetition, Problem-What, Ask-for-Information, Knowledge Evaluation, Problem-Gap, Problem-Hypothesis, Paraphrase, New Knowledge, Verification, Inference, and Elaboration. Unlike Latifah (2002), we did not find Anticipation to be a metacognitive strategy in junior high school students.

When the metacognitive strategies found in this research were analyzed based on Perfetti's dichotomy (1989), they could be categorized into two groups: (1) strategy aimed at gaining meaning from a text; and (2) strategy that aims to achieve interpretation of a text. There are seven metacognitive strategies included in the first category: Problem-Awareness, Text Evaluation, Reread, Repetition, Problem-What, Ask-for-Information, and Paraphrase. Meanwhile, the strategies included in the second category are Inference and Elaboration. According to Suradijono (2003), the rest of the 6 types (Meaning, Knowledge Evaluation, Problem-Gap, Problem-Hypothesis, New Knowledge, and Verification) are considered transitional strategies.

The strategies included in Perfetti's second category (1989) can be categorized as high-level metacognitive strategies because in the process of gaining reading comprehension, the individuals using these strategies must perform more complex information processing than just achieving an understanding of the text. We can conclude that inference and elaboration are two kinds of high-level metacognitive strategies, while the rest of the thirteen types are considered low-level ones.

The results of this study prove that students use metacognitive strategies when faced with reading tasks. This proves the existence of metacognitive awareness, or junior high school students' ability to think about their own thought processes (Flavel, 1979).

The results of this study indicate that Reread and New Knowledge are two types of metacognitive strategies with the highest frequency of use. Problem-What and Ask-forInformation are also fairly high-use strategies. In contrast, Elaboration and Verification are two types of high-level strategies that saw very little use. This fact indicates that junior high school students in the upland region of Java mostly use low-level strategies according to Perfetti's dichotomy (1989) when faced with reading assignments.

The fact that junior high school students in the upland region of Java only use two types of highlevel metacognitive strategies, while junior high school students in Bogor (Sundanese tribes that are nearer to the city) use three types of high-level metacognitive strategies indicates that cultural context and social environment play a role in student use of metacognitive strategies. The results of this study are consistent with the results of other studies, including research on metacognitive strategies in children of West Germany and the United States (Carr, Kurtz, Schneider, Turner, \& Borkowski, 1989), as well as research on Filipino and Korean students (Turingan \& Yong-Chil, 2009). Based on the Bronfenbrenner Ecological Systems Theory, the differences in geographical, cultural and ethical environments have an impact on individuals' developmental differences in both areas because the environment shapes the character and values of society (Darling, 2007). The differences in metacognitive strategies among these regions can also be explained by the 
theory of Vygotsky (1978), which assumes that all psychological processes originate from the outside (social) and are then transformed to someone (intrapersonal) through experiences supported by others. Thus, different regional sociocultural contexts can influence individual development of metacognitive strategies in the region. This is a result of individual social interactions with the environment around where the individuals live (McKeown, Beck, \& Blake, 2009).

The result of the statistical test of research data in the upland region of Java also proves the influence of metacognitive strategies on reading comprehension. The results of this study align with the results of other studies (Williams \& Atkins, 2009; Kolić-Vehovec, et.al, 2010). Thus, the results of this study further strengthen the support of the proposition that metacognition plays an important role in reading comprehension.

Bazerman (1985) and Pressley and Afflerbach (1995) have proven that success in comprehending reading materials depends on directed cognitive effort. This refers to the metacognitive processing which involves knowledge and regulation of the thinking processes. According to Alexander and Jetton (2000), during the process of reading, metacognitive information processing is expressed through reader strategies that are procedural, purposive, and full of effort. In the process of comprehending the reading, the individual must intend to and deliberately present a strategy, and must make an effort to organize and improve his comprehension of the material he reads (Alexander \& Jetton 2000). Using metacognitive strategies helps readers devote significant attention to controlling, monitoring, and evaluating the reading process (Pressley, 2000; Pressley, Brown, El-Dinary, \& Afflerbach, 1995). Thus, when able to read the text, the individual must proactively monitor and regulate the use of metacognitive strategies to achieve comprehension. This is evidenced by the results of this study, which show the influence of the use of metacognitive strategies on reading comprehension.

The findings of this study indicate that the use of metacognitive strategies of students in the upland region of Java needs to be further improved to achieve better reading comprehension. Therefore, in the next study, it is advisable to formulate an appropriate metacognitive scaffolding model for junior high school students in the upland region, and to conduct research on the effectiveness of the model. In closing, we would like to point out some limitations. Our study was limited to only one region; that is, the upland area in East Java. We believe that the strategies used by upland people in Central Java are not same as that of East Java.

\section{References}

Alexander, P.A., \& Jetton, T.L. (2000). Learning from text: A multidimensional and developmental perspective. In M.L. Kamil, P.B. Mosenthal, P.D. Pearson, \& R. Barr (Eds.), Handbook of reading research (Vol. 3, pp. 285-310). Mahwah, NJ: Erlbaum.

Bazerman, C. (1985). Physicist reading physics: Schema-laden purposes and purpose-laden schema. Written Communication 2(1), 3-23.

Block, C.C. (2004). Teaching comprehension: The comprehension process approach. Boston: Pearson Education, Inc.

Brown, A.L. \& Palincsar, A.S. (1989). Guided, Cooperative Learning and Individual Knowledge Acquisition. In L. B. Resnick (Ed), Knowing, Learning, and Instruction: Essay in Honor of Robert Glaser (pp. 393-451). New Jersey: Lawrence Erlbaum.

Carr, M., Kurtz, B. E., Schneider, W., Turner, L. A., \& Borkowski, J. G. (1989). Strategy acquisition and transfer among American and German children: Environmental influences on metacognitive development. Developmental Psychology, 25(5), 765-771. 
Chall, J. S. (1979). The great debate: Ten years later with a modest proposal for reading stages. In L. B. Resnick \& P. A. Weaver (Eds.), Theory and practice of early reading. Hillsdale. NJ: Erlbaum.

Darling, N. (2007). Ecological systems theory: The person in the center of the circles. Research in human development, 4(3-4), 203-217.

Dorn, L.J., \& Soffos, C. (2005). Teaching for deep comprehension: A reading workshop approach. Maine: Stenhouse Publishers.

Flavell, J. H. (1979). Metacognition and cognitive monitoring: A new era of cognitive-developmental inquiry. American Psychologist, 34(10), 906-911. doi:10.1037/0003-066x.34.10.906

Irianto, A. M. \& Thohir, M. (2000). Membangun Rasa Damai di Atas Bara. Semarang: Limpad

Jatman, D. (1993). Sekitar Masalah Kebudayaan. Bandung: Penerbit Alumni.

Jonassen, D.H. (1987). Integrating learning strategies into courseware to facilitate deeper processing. In F. E. Weinert \& P. Kline (eds). Metacognition, Motivation and Understanding (pp. 151-181). Hillsdale, NJ: Lawrence Erlbaum Associates.

Karbalaei, A. (2011). Metacognition and reading comprehension. Íkala, revista de lenguaje y cultura, 16(28), 5-14.

Kintsch, W. (1998). Comprehension: A paradigm for cognition. Cambridge, UK: Cambridge University Press.

Klingner, J.K., Vaughn, S., \& Boardman, A. (2007). Teaching reading comprehension to students with learning difficulties. New York, NY: The Guilford Press.

Koda, K. (2007). Reading language learning: Crosslinguistic constraints on second language reading development. Language Learning, 57(1), 1-44. http://dx.doi.org/10.1111/0023-8333.101997010-i1

Kolić-Vehovec, S., Bajšanski, I., \& Zubković, B. R. (2010). Metacognition and reading comprehension: Age and gender differences. In A. Efklides \& P. Misailidi (Eds.). Trends and prospects in metacognition research (pp. 327-344). New York: Springer.

Kozulin, A. (2003). Psychological tools and mediated learning. In A. Kozulin, B. Gindis, V. S. Ageyev, \& S. M. Miller (Eds.). Vygotsky's educational theory in cultural context. Cambridge: Cambridge University Press.

Latifah, M. (2002). Strategi-strategi Kognitif yang Digunakan oleh Pakar (Expert) dan Non Pakar (Novice) dalam Membaca (Suatu penelitian tentang penggunaan strategi kognitif dalam proses pemahaman bacaan eksposisi pada siswa Sekolah Lanjutan Tingkat Pertama). (Unpublished master's thesis). Universitas Indonesia, Jakarta.

Lenski, S. D., \& Nierstheimer, S. L. (2002). Strategy instruction from a sociocognitive perspective. Reading Psychology, 23(2), 127-143.

McKeown, M. G., \& Beck, I. L. (2009). The role of metacognition in understanding and supporting reading comprehension. In D. J. Hacker, J. Dunlosky, \& A. C. Graesser (Eds.). Handbook of Metacognition in Education (pp. 7-25). New York, NY: Routledge.

McKeown, M. G., Beck, I. L., \& Blake, R. G. (2009). Rethinking reading comprehension instruction: A comparison of instruction for strategies and content approaches. Reading Research Quarterly, 44(3), 218-253.

McNamara, D. S. (2007). Reading comprehension strategies: Theories, interventions, and technologies (5th ed.). New Jersey: Lawrence Erlbaum.

Nation, K., Clarke, P., \& Snowling, M. J. (2002). General cognitive ability in children with reading comprehension difficulties. British Journal of Educational Psychology, 72(4), 549-560.

Perfetti, C. A. (1989). There are generalized abilities and one of them is reading. Knowing, learning, and instruction: Essays in honor of Robert Glaser, 307-335.

Pressley, M. (2000). What should comprehension instruction be the instruction of? In M.L. Kamil, P.B. Mosenthal, P.D. Pearson, \& R. Barr (Eds.), Handbook of Reading Research (Vol 3). Mahwah, NJ: Erlbaum.

Pressley, M., \& Afflerbach, P. (1995). Verbal protocols of reading: The nature of constructively responsive reading. Hillsdale, NJ: Erlbaum.

Pressley, M., Brown, R., El-Dinary, P., \& Afflerbach, P. (1995). The comprehension instruction that students need: Instruction fostering constructively responsive reading. Learning Disabilities Research \& Practice, 10(4), 215-224.

Santrock, J.W. (2011). Educational Psychology (5th ed.). New York, NY: McGraw-Hill.

Scardamalia, M., \& Bereiter, C. (1985). Fostering the development of self-regulation in children's knowledge processing. Thinking and learning skills, 2, 563-577.

Schunk, D.H., Pintrich, P.R., Meece, J.L. (2008). Motivation in education: Theory, research, and applications (3th ed.). New Jersey, NJ: Pearson Education.

Snow, C. (2002). Reading for understanding: Toward a research and development program in reading comprehension. Science \& Technology Policy Institute. Santa Monica, CA: RAND.

Suradijono, S.H. (1989). The Relation of Self-reported Knowledge Lacks to Understanding. (Unpublished master's thesis). University of Toronto, Toronto.

Suradijono, S.H. (1999). Strategi Belajar Siswa Sekolah Menengah Umum dengan Teks Linear dan Non-Linear. (Laporan penelitian). University Research for Graduate Education (URGE) Project). Jakarta.

Tierney, R., \& Pearson, D. (1994). Learning to learn from text: A framework for improving classroom practice. In R. Ruddell, M. Ruddell, \& H. Singer (Eds.), Theoretical models and processes of reading (4th ed.) (pp. 496-513). Newark, DE: International Reading Association.

Turingan, J.P. \& Yong-Chil, Yang. (2009). A cross-cultural comparison of self-regulated learning skills between Korean and Filipino college students. Asian Social Science. 2009. Vol. 5 (12): 3-10.

Van der Veer, R. (2007). Lev Vygotsky. London: Continuum. 
Vygotsky, L. S. (1978). Mind in society: The development of higher psychological processes. Cambridge, MA: Harvard University Press.

Williams, J.P., \& Atkins, J.G. (2009). The role of metacognition in teaching reading comprehension to primary students. In D. J. Hacker, J. Dunlosky, \& A. C. Graesser (Eds.). Handbook of Metacognition in Education (pp. 26-44). New York, NY: Routledge.

Winne, P. H., \& Nesbit, J. C. (2009). Supporting self-regulated learning with cognitive tools. In D. J. Hacker, J. Dunlosky, \& A. C. Graesser (Eds.). Handbook of Metacognition in Education (pp. 259-277). New York, NY: Routledge.

Zimmerman, B. J. (1990). Self-regulated learning and academic achievement: An overview. Educational Psychologist, 25 (1), 317. 